\title{
TERAPI DENGAN PANAX GINSENG "BING HAN" SALAH SATU ALTERNATIF MENATAP MASA DEPAN YANG CERAH BAGI PENDERITA DIABETES DAN KOMPLIKASINYA
}

Oleh : Subagyo

Dosen Jurusan Pendidikan Olahraga FIK Unesa Surabaya

\begin{abstract}
Abstrak
Artikel ini ditulis berangkat dari pengalaman pribadi penulis yang selama 3 tahun
\end{abstract} ini mengalami sakit yang menurut banyak teman merupakan sakit yang aneh dan hebat. Aneh karena jarang ditemui di masyarakat. Analisis dokter katanya SJS tapi ada juga yang menyatakan sebagai Psoriasis Eritroderma. Penulis kurang memahami tentang jenis penyakit ini yang jelas berkaitan dengan Immunitas tubuh. Sampai suatu waktu divonis dokter tidak ada obatnya. Tapi penulis percaya bahwa Tuhan akan memberikan ampunan dan pertolongan pada hambanya yang mau berusaha dan bertawakal.

Berawal dari Alergi hebat sehingga terjadi pembengkakan pada kepala penulis, sehingga sampai tidak bisa melihat dengan kata lain mata saya tertutup oleh bengkak. Kemudian kulit mengelupas seperti Ular "nelungsungi" dalam bahasa jawa. Pada akhirnya penulis mengalami banyak komplikasi penyakit. Selama 3 tahun ini penulis keluar masuk rumah sakit lebih dari 10 kali, sampai pada maret 2012 kemarin penulis menemukan terapi yang meringankan penderitaan penulis hingga bisa masuk kerja lagi. Yang pertama terapi dengan akupresure dan pemanasan mengunakan sinar inframerah jauh (SIM J) memakai batu keramik turmanium dan terapi minum powder ginseng untuk memperbaiki keenam sistem dalam tubuh. Hasilnya sangat "ajaib", penulis mengalami kemajuan yang revolusioner membaik. Pengalaman ini mendorong penulis untuk mengkaji dan mencari referensi kenapa dan bagaimana terutama kerja ginseng dari referensi yang ada dan mencoba mengkaitkan dengan keenam sistem dalam tubuh manusia.

Keenam sistem utama dalam tubuh manusia adalah 1) sistem hormon, 2) sistem sirkulasi, 3) sistem metabulasi, 4) sistem syaraf Otonomic, 5) sistem daya Immunitas, dan 6) sistem Bakteri positif Usus. Dengan terapi yang sesuai dengan "Bing Han" ginseng maka keenam sistem ini akan diperbaiki, sehingga penyakit yang diderita seseorang secara progresive dapat disembuhkan tanpa ada efek samping.

Kata Kunci : Panax Ginseng “bing Han”, Penyakit, 6 sistem utama tubuh

Pada akhir tahun 2009 penulis mulai menderita sakit alergi yang hebat, pada waktu itu sedang persiapan pertandingan Tenis Lapangan menghadapi event 2 tahunan LPTK Cup. Penulis ke dokter, karena ada alergi yang reaksinya gatal-gatal di tubuh. Penulis ke dokter, maksudnya ke dokter spesialis tapi pada saat itu banyak dokter spesialis kulit yang ikut seminar di Bogor, sehingga penulis ke dokter umum. Penulis mendapatkan injeksi, entah apa yang diinjeksikan yang jelas terjadi penolakan pada tubuh penulis. Pada hari Senin dan Kamis penulis mendapat injeksi, hari jumatnya penulis tugas ke Jogyakarta untuk seminar. Di Jogyakarta inilah awal sakit penulis, reaksi dari penolakan injeksi karena ada Alergi sehingga penulis Opname selama 6 hari di Rumah Sakit Umum dr. Sarjito Jogyakarta. 


\section{MEDIKORA Vol. IX, No 1 Oktober 2012}

Setelah pulang dari rumah sakit dr.Sarjito penulis berobat jalan, dan sempat tes Alergi dan hasilnya memang penulis alergi hebat hampir semua makanan yang biasanya tidak masalah menjadi pantangan bagi penulis menurut petunjuk dokter, praktis penulis hanya diperbolehkan mengkonsumsi daging merah dan sayur-sayuran saja, unggas tidak boleh juga. Buah-buahan tertentu juga tidak boleh dikonsumsi. Setelah itu ada gejala dalam tubuh penulis mulai ada pengelupasan lapisan kulit. Hampir seluruh lapisan kulit mengelupas termasuk kulit kepala.

Efek pengobatan kulit tanpa penulis ketahui ternyata meningkatkan gula darah, sehinngga pada akhir tahun 2009 penulis dehidrasi dan melakukan perawatan di RumahSakit. Di rumah sakit inilah penulis dirujuk ke dokter penyakit Dalam, dokter Mata, dokter THT, dokter Syaraf, dan dokter Paru-paru, inilah awal mula penulis menderita sakit dan selama tiga tahun ini keluar masuk rumah sakit, terakhir masuk rumah sakit pertengahan Maret 2012 dan pada akhirnya menemukan Panax Ginseng "Bing Han” sebagai Nutrisi untuk terapi, karena penulis ada Alergi termasuk pada obat-obatan tertentu sehingga praktis penulis tidak berani minum obat sistemik jadi hanya injeksi insulin saja untuk mereduksi gula darah dan bantuan Nutrisi Ginseng "Bing Han" untuk terapi, alhamdulillah atas ijin Allah penyakit yang penulis derita mulai membaik sehingga penulis bisa kembali aktif bekerja sebagaimana sedia kala dan mudah-mudahan kesembuhan penulis ini adalah kesembuhan yang permanen, amin.

\section{PENYEBAB MUNCULNYA PENYAKIT MODERN}

\section{A. Sumber Penyakit}

Tubuh manusia terbentuk lebih dari 60 trilyun sel, setiap grup sel mempunyai tugas dan fungsi masing-masing. Jika sel-sel atau group sel yang dimaksud sehat serta aktif, maka masing-masing organ akan berfungsi dengan normal dan tubuh kitapun akan sehat. Untuk menjaga agaistihrr group sel dan tubuh kita sehat diperlukan nutrisi yang cukup dan seimbang, istirahat yang cukup, gerak yang cukup, dan oksigen yang cukup.

Kenyataan saat ini lingkungan kita kurang mendukung, demikian juga dengan pola hidup dan kebiasaan makan yang kurang sehat, terjadinya pencemaran pada udara, kualitas air dan makanan yang kurang baik, terutama setelah revolusi Industri, yang telah membuat ekonomi booming, sehingga terjadi pencemaran zat kimia di bumi dan daerah aliran perairan dalam skala besar. Dengan efek pemadatan pada food-chain, daur ulang, pemupukan, yang akhirnya mengakibatkan kerusakan pada fungsi jaringan organ dan mutasi gen dalam tubuh konsumen. Terdapat hubungan yang cukup erat antara polutan 


\section{MEDIKORA Vol. IX, No 1 Oktober 2012}

dan penyakit kanker atau penyakit peradaban. Pestisida, pupuk kimia, hormon pertumbuhan, polusi udara, obat-obatan merupakan faktor utama. Penyakit kanker disebabkan oleh terjadinya mutasi sel, dan pada orang yang sehat kadang-kadang juga terdapat jenis sel-sel kanker anaerobian, apabila tubuh kita tidak menciptakan atau mengkondisikan oksigen yang cukup dan melakukan pembakaran yang cukup maka akan memberikan peluang tumbuh dan berkembangnya sel-sel kanker, sehingga olah raga atau olah gerak akan membantu mengkondisikan penghambatan pertumhan sel kanker.

\section{B. pH Tubuh Yang Bersifat Asam dapat Menimbulkan Penyakit Modern}

Penyakit modern telah mengalami proses transpormasi ; dahulu pada zaman masyarakat pertanian yang masih terbelakang, penyakit utamanya adalah kolera, desentri, tubercolosis (TBC), dan sebagainya; penyakit menular yang diakibatkan oleh bakteri pathogen, namun dengan penemuan zat antibiotik, kebanyakan penyakit tidak diakibatkan oleh bakteri pathogen, namun yang menggantikannya antara lain adalah : penyakit kanker, penyakit jantung, stroke, penyakit diabetes melitus (kencing manis) dan penyakit ganas lainnya, yang setiap saat mengerogoti jiwa dan raga orang masa kini. Setelah dikaji oleh berbagai peneliti, penyakit-penyakit ini semua diakibatkan oleh "pH tubuh yang bersifat asam".

1.

pH Tubuh yang Bersifat Asam

\section{Merusak Jiwa dan Raga.}

pH tubuh yang asam merusak "daya penyembuhan alami” (yakni daya imun, reaksi enzimter yang semakin aktif meningkatkan daya imun), ketika cairan tubuh menjadi asam maka reaksi enzim menjadi lamban, aneka fungsi tubuh menjadi kian mengendur dan sangat rentan terhadap aneka jenis penyakit.

2.

Penyebab pH tubuh menjadi Asam

dari berbagai kajian peneliti dapat disimpulkan sebagai berikut ;

a. Mengkonsumsi terlalu banyak beras yang terlalu putih, minuman berolkohol, daging, jajanan manis dan makanan lainnya yang pHnya bersifat asam.

b. Minum dan makan yang berlebihan serta mengkonsumsi terlalu banyak makanan yang mengandung bahan tambahan synthetisyang tidak dapat teruraikan dan diserap oleh tubuh, sehingga terjadi penimbunan racun dalam tubuh.

c. Kurangnya berolahraga sehingga makanan tidak dapat diuraikan "terbakar" secara sempurna, sehingga menimbulkan materi tidak murni di dalam tubuh.

d. Perasaan hati yang terlalu tegang dan beban kehidupan yang terlalu berat (stress). 


\section{MEDIKORA Vol. IX, No 1 Oktober 2012}

3.

BING HAN Ginseng powder

hasil riset yang dilakukan oleh Prof. Dr. Li He Shun beserta 40 Profesor lainnya pada tahun 1989 di Hai Chang Shien China dan telah dipatenkan memiliki kandungan lebih dari 160 jenis Vitamin dan Mineral yang sangat diperlukan untuk menjaga keseimbangan hawa tubuh inti (Chii) dan merubah darah dari asam menjadi basa. Kesehatan merupakan keseimbangan dari berbagai organ dan berbagai sistem didalam tubuh kita. Jika fungsi tubuh melebihi atau kurang dari tingkat keseimbangan, maka pada saat itu penyakit akan timbul. Prinsip ini pertama kali ditemukan oleh dokter dari Yunani pada pertengahan abad V sebelum Masehi dan tetap berlaku sampai sekarang. Oleh karena itu untuk mengobati atau menyembuhkan, bahkan untuk mencegah penyakit sangat tergantung pada pemeliharaan atau pembentukan kembali keseimbangan alami hawa tubuh inti manusia (Chii) dan itulah salah satu khasiat BING HAN Powder Ginseng. Pengobatan pada bagian tubuh tertentu yang sakit di dunia kedokteran modern, dalam waktu yang relatif rutin, maka akan menimbulkan akibat lanjutan dalam jangka panjang yang efek dan pengaruhnya dapat dilihat dari arah panah pada gambar 1, yakni 5 elemen yang sakit berkaitan dan mempengaruhi berikut ;

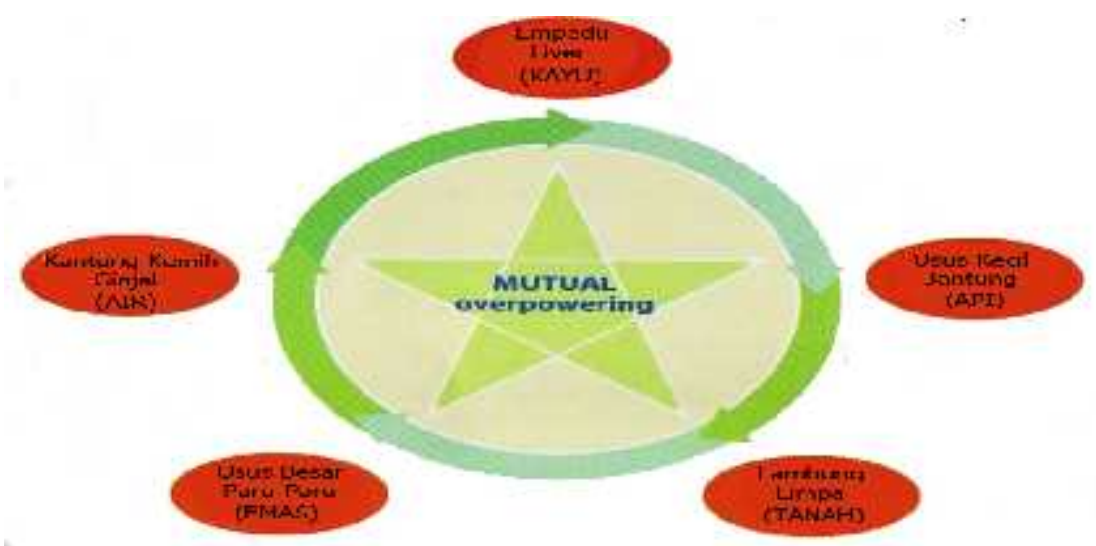

Gambar 1. Lima Elemen Tubuh yang Bisa Sakit

C.

\section{Lamanya Proses Penyembuhan}

Untuk seseorang yang sehat sampai terdiagnosa suatu penyakit (pathogenesis) sedikitnya memerlukan waktu 15 tahun, dan untuk berkembang menjadi kanker memerlukan waktu 20 tahun. Jika seseorang merasakan adanya berbagai gejala tidak enak badan, berarti sudah terjadi gejala penuaan pada organ dalam (viscera) atau jaringan lainnya. Pada tahapan ini belum bisa dideteksi ilmu kedokteran masa kini, karena dari 


\section{MEDIKORA Vol. IX, No 1 Oktober 2012}

gejala gangguan sampai menjadi wujud penyakit masih ada proses yang memerlukan waktu sekitar 5 - 10 tahun untuk bisa dideteksi. Oleh kare itu jenis penyakit yang terdeteksi umumnya sudah terlambat, atau sudah masuk stadium akhir untuk yang menderita kanker.

Secara singkat metabolisme adalah suatu proses pembaharuan yang terus berlanjut dan berkesinambungan. Tubuh manusia merupakan suatu kosmos mini, bahan paling baku yang membentuk tubuh manusia adalah sel, karena adanya atom, molekul dan elektron dalam sel, maka timbulah kehidupan, sel-sel manusia terus menerus menyerap gizi dalam prosesnya, disamping terus membuang limbah dan unsur toksin.

Pada tabel1, berikut ini dapat disimak sekilas waktu metabolisme tubuh manusia, karena waktu yang dibutuhkan penyembuhan penyakit, berkaitan erat dengan waktu metabolisme tubuh manusia.

Tabel 1. Waktu Metabolisme Tubuh Manusia

\begin{tabular}{|l|l|}
\hline Waktu metabolisme kulit (dermal) & $4-6$ bulan \\
\hline Waktu metabolisme daging (muscle) & $2-3$ tahun \\
\hline Waktu metabolisme otot (tendon) & $3-5$ tahun \\
\hline Waktu metabolisme tulang & Diatas 7 tahun \\
\hline
\end{tabular}

Karena tubuh manusia mempunyai hukum alam tersendiri, di samping karena kekeliruan (misledeading) kalangan medikal masa kini sehingga manusia kini tidak menemukan kondisi terbaik guna menunjang tubuh manusia melakukan berbagai metabolisme secara sempurna, akibatnya nyaris semua penderita sakit sulit disembuhkan secara medis atau alami, sekalipun tergantung pada obat seumur hidup. Jika seseorang ingin mempercepat waktu penyembuhan, pembuangan unsur toksin harus diintensifkan. Untuk itu ia akan membutuhkan lebih banyak gizi guna menunjang proses pembuangan besar-besaran unsur toksin dalam tubuh, karenanya ia akan menderita saat terjadi proses ini. Tetapi hal ini tergolong proses reaksi penyembuhan, mengiringi terbuangnya unsur toksin dalam tubuh, sakit yang dideritanya akan berangsur sembuh.

D.

\section{Powder}




\section{MEDIKORA Vol. IX, No 1 Oktober 2012}

BING HAN Ginseng Powder mempunyai fungsi setingkat lebih tinggi dari makanan kesehatan dan juga memiliki fungsi untuk membenahi dan menormalkan kembali fungsi kelima organ tubuh yang kacau atau rusak, bekerja dengan cara memulihkan daya penyembuh alami tubuh, memberi keseimbangan Ying Yang, memberi nutrisi yang kurang, membuang toksin/racun, membersihkan darah dari asam menjadi basa. Dengan daya penyembuh alami maka keenam sistem dalam tubuh bekerja secara normal dan seimbang seiring dengan ini penyakit mulai disembuhkan secara alami. Keenam sistem dalam tubuh tersebut tercermin dalam gambar 2 berikut :

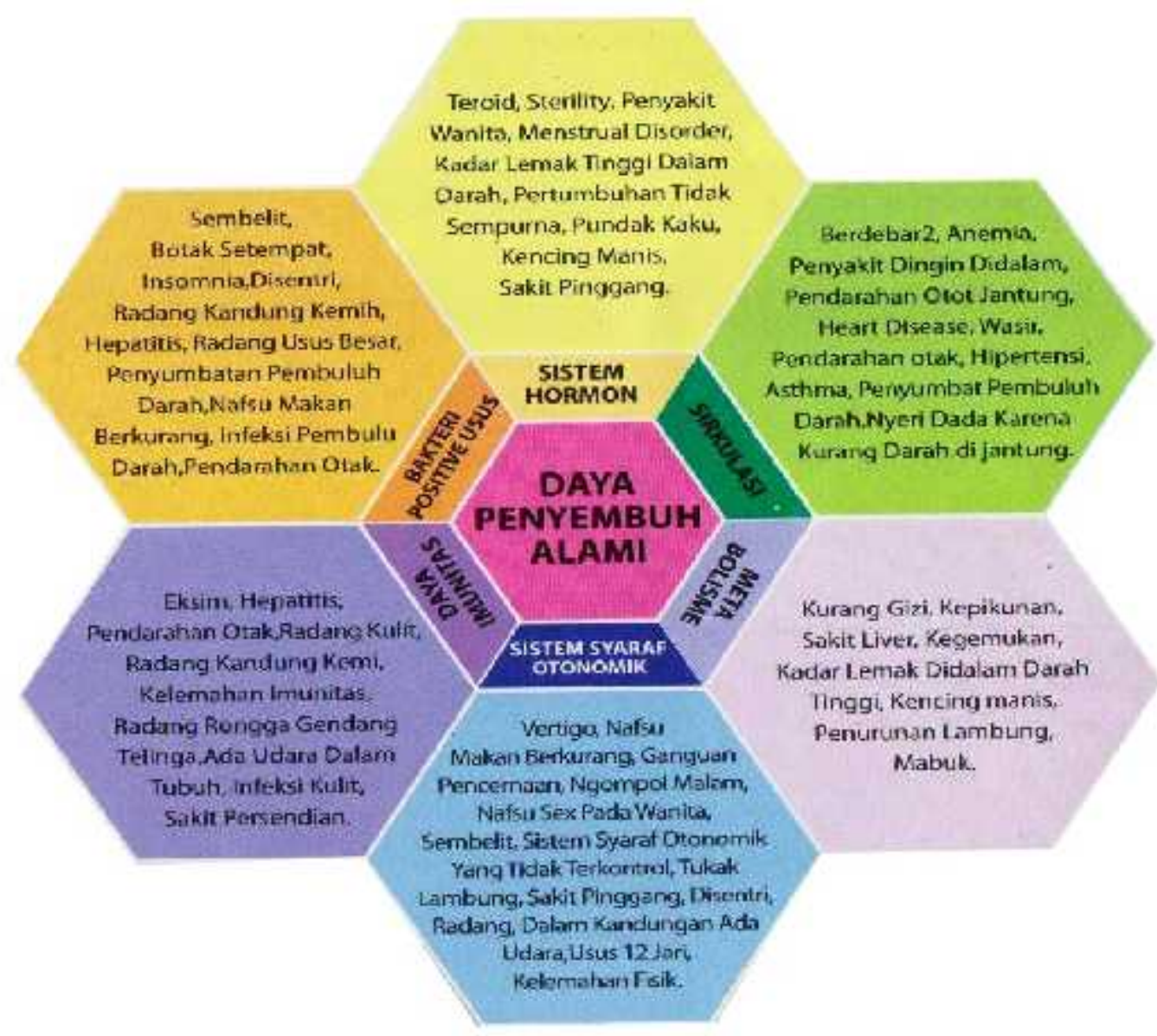

Gambar 2. Enam sistem dalam tubuh

E.

\section{Pembuktian Ilmu Kedokteran}

Para ilmuwan yang meneliti ginseng, menjelaskan bahwa kandungan aktif ginseng sangat penting untuk menjaga kesehatan terutama dengan meningkatnya resiko masalah kesehatan yang bertautan dengan bertambahnya usia. Artikel yang diterbitkan dalam journal of Ethnopharmacology pada tahun 2006 dan 2007 oleh para peneliti di perguruan 


\section{MEDIKORA Vol. IX, No 1 Oktober 2012}

tinggi medis di China menyimpulkan bahwa ginsenosides membantu mengontrol penuaan otak dan mendukung kesehatan syaraf otak.

Peneliti di Austria dan Spanyol juga mengatakan bahwa ginsenosides Panax Gingseng dapat mendukung aktifitas syaraf dan menunjukkan bahwa ginseng adalah pilihan bagus untuk mningkatkan kesehatan syaraf. Dokter-dokter di Mesir juga mengadakan penelitian tentang ginseng dan hasil ulasan mereka diterbitkan dalam Journal of Pharmacological Science (jurnal Ilmu Parmakologi). Para dokter tersebut juga mengkonfirmasikan bahwa ginseng sangat bermanfaat dalam proses penuaan dan menghasilkan dampak positif dalam masalah yang berkaitan dengan syaraf.

Sumber Journal of Ethnopharmacology (2006, 2007, Acta Neurobioliae Experimenatlis 2005, 2006), Journal of Pharmacological Sciences (2006) mengulas masalah sebagai berikut :

1. Tentang Tonik yang menyegarkan diulas oleh Radad K, Gille G, Liu L, Rausch WD dalam Journal of Pharmacological Sciences, 2006 Mar; 100(3): 175-86. Epub 2006 Mar 4. Assiut Univercity, Egypt, dengan Judul ; Pengunaan ginseng dalam pengobatan dengan penekanan pada gangguan kesehatan yang berkaitan dengan kemunduran fungsi syaraf.

2. Tentang Anti penuaan diulas oleh Shen LH, Zhang JT dalam Journal of Neurological Research, 2004 Jun; 26(4):422-8, Beijing, China, dengan Judul; Ginsenosida Rg1 meningkatkan proliferasi sel progenitor hippocampal.

3. Tentang aktifitas Yin/Yang ginseng anti tumor oleh Yeu PY, Mak NK, Cheng YK, Leung KW, NgTB, Fan DT, Yeung HW, Wong RN dalam Journal Chinese Medecine, 2007 May 15; 2:6, Kowloon Tong, Hong Kong SAR, China, dengan judul; Pharmacogenomics dan Aktifitas Yin/Yang ginseng : anti-tumor, angiomodulasi dan aktifitas ginsenosides yang mirip steroid.

4. Tentang Kulit yang awet muda, menjadikan permukaan kulit halus oleh Lee J., Jung E, Lee J, Huh S, Kim J, Park M, So J, Ham Y, Jung K, Hyun CG, Kim YS, Park D. Dalam Journal of Ethnopharmacology, 2007 Jan 3; 109(1):29-34, Epub 2006 Jul 3, Gunpo City, 435-833 Gyunggi Do, Republic of Korea, dengan Judul; Panax ginseng menginduksi tipe I kolagen manusia melalui aktivasi sinyal Smad.

5. Tentang melindungi sel otak dan sel saraf oleh Rausch WD, Liu S, Gille G, Radad K, Dalam Journal Acta Neurobiol Exp (Wars), 2006; 66(4):369-75, Veterindirplatz, 1 A1210 Vienna, Austria, dengan Judul; Efek perlindungan saraf dari ginsenosides. 


\section{MEDIKORA Vol. IX, No 1 Oktober 2012}

6. Tentang Ginsenosides untuk Kesehatan Otak oleh, Xue JF, Liu ZJ, Hu JF, Chen H, Zhang JT, Chen NH, Dalam Journal Brain Research, 2006 Aug 23; 1106(1):91-8. Epub 2006 Jul 11, Beijing 100050, China, dengan Judul; Ginsenosida RB1 meningkatkan pelepasan neurotransmiter dengan cara modulasi fosforilasi synapsins melalui jalur cAMP-dependent kinase protein.

7. Tentang Pelindung sel otak diulas oleh Cheng Y, Shen LH, Zhang JT, dalam journal Acta Pharmacologia Sinica, 2005 Feb; 26(2):143-9, Beijing 100050, China, dengan Judul; Efek ginsenosida Rg1 dan RB1 sebagai anti-amnesia dan anti-penuaan beserta mekanisme kerjanya.

8. Tentang Pelindung Selular diulas oleh Geetha T, Saini A, Kaur IP, Dalam Jurnal Indian Journal of Experimental Biology, 2006 Oct; 44(10):838-41, Chandigarh 160 014, India, dengan Judul; Ekstrak Ginseng menunjukkan aktivitas anti-mutagenik terhadap mutagenesis induksi dalam berbagai strain salmonella typhimurium.

9. Tentang ginseng memberi perlindungan anti oksidan ke Otak diulas oleh; Lopez MV, Cuadrado MP, Ruiz-Poveda OM, Del Fresno AM, Accame ME, dalam Journal Biochim Biophys Acta 2007, 1770(9): 1308-16, Epub 2007 Jun 28, Madrid, Spain, dengan Judul : Efek individu ginsenosides sebagai pelindung saraf pada pembiakan astrosit primer.

10. Tentang Efek Anti-inflamasi Ginseng diulas oleh Choi K, Kim M, Ryu J, Choi C, dalam Journal Neuroscience Letters, 2007 Jun 21; 421(1):37-41. Epub 2007 May 22, Daejeon 305-701, Republic of Korea, dengan Judul Senyawa K Ginsenosides dan Rh (2) menghambat aktivasi nekrosis faktor induksi-alfa tumor NF-KappaB dan jalur JNK dalam sel astroglial manusia.

11. Tentang kesehatan jantung dan kardiovaskular oleh Jiang QS, Huang XN, Dai ZK, Yang GZ, Zhou QX, Shi JS, Wu Q dalam Journal of Ethnopharmacology 2007 May 22; 111(3):567-72. Epub 2007 Jan 12. 400016 Chongqing, China, Dengan Judul; Efek Penghambatan ginsenosida RB1 pada hipertrofi Jantung yang diinduksi oleh monocrotaline pada tikus.

12. Tentang memperbaiki Sirkulasi Darah diulas oleh Sun K, Wang CS, Guo J, Horie Y, Fang SP, Liu YY, Liu LY, Yang JY, Fan JY, Han JY, dalam Journal Life Sciences, 2007 Jul 19; 81(6):509-18. Epub 2007 Jun 28. Beijing, China, Dengan judul Efek pelindung dari ginsenosida Rb1, ginsenosida Rg1, dan notoginsenoside R1 pada organ dalam perut tikus yang mengalami gangguan microcirculatory yang diinduksi dengan lipopolisakarida. 


\section{MEDIKORA Vol. IX, No 1 Oktober 2012}

13. Tentang gula darah diulas oleh Lee WK, Kao ST, Liu IM, Cheng JT, dalam journal Hormone and Metabolic Research, 2007 May; 39(5):347-54, Taichung City, Taiwan, RO China, dengan Judul; Ginsenosida Rh2 adalah salah satu kandungan aktif dariakar ginseng Panax yang dapat meningkatkan sensivisitas insuline dalam tikus-tikus yang diberi makanan kaya fruktosa.

14. Tentang berat badan yang sehat diulas oleh Karun N, Reifen R, Kerem Z, dalam Journal of Agricultural and Food Chemistry 2007 Apr 18; 55(8):2824-8. Epub 2007 Mar 17, Jerusalem, Rehovot, Israel, dengan judul; Pengurangan berat badan tikus yang diberi Panax ginseng saponin, sebuah penghambat lipase pankreas.

15. Tentang Ginseng mengurangi resiko kardiovaskular diulas oleh Kim JH,Cho SY, Kang CW, Yoon IS, Lee JH, Jeong SM, Lee BH, Lee JH, Pyo MK, Choi SH, Quan SF,Lee JH, Choi CB, Rhim H, Nah SY, dalam Journal Biological and Pharmaceutical Bulletin, 2006 Dec; 29(12):2425-31, Seoul, Republic of Korea, dengan Judul; Ginseng saponin mengurangi efek buruk vaskular yang terkait dengan hyperhomocysteinemia kronis yang diinduksi oleh metionin.

16. Tentang mengurangi gejala Alergi diulas oleh Park EK, Choo MK, Han JH, Kim DH, dalam Jurnal International Archives of Allergy and Immunology, 2004 Feb; 133(2):113-20. Epub 2004 Jan 21, Kyung Hee University, Seoul, Republic of Korea, dengan Judul Ginsenosida Rh1 memiliki aktivitas anti-alergi dan anti-inflamasi.

17. Tentang pelindung dari efek Radioaktif diulas oleh $\mathrm{C}$ Jagetia $\mathrm{G}$, dalam Journal of Clinical Biochemistry and Nutrition, 2007 Mar; 40(2):74-81. Kasturbal Medical College, Manipal-576 104, India, Dengan Judul; Potensi Radioprotective Tumbuhan dan Herbal terhadap efek Pengion Radiasi.

18. Tentang meningkatkan kesuksesan Hasil Bedah diulas oleh Xia ZY,Liu XY, Zhan LY, He YH, Luo T, Xia Z, dalam Journal of Thoracic and Cardiovascular Surgery, 2005 Aug; 130(2):258-64, Wuhan University, China, dengan Judul; Ginsenosides senyawa (shen-fu) menipiskan cedera gastrointestinal dan menghambat respon inflamasi setelah cardiofulmonary bypass pada pasien dengan penyakit jantung bawaan.

19. Tentang pencegah Kanker diulas oleh Yun TK dalam Jurnal Lancet Oncology,2001 Jan;2(1):49-55, Seoul, Republic of Korea, dengan judul Panax ginseng - pencegah Kanker non-organ-spesifik.

20. Tentang ginseng untuk Kesehatan Imunitas diulas oleh Shin HY, Jeong HJ; Hyo-JinAn, Hong SH, Um JY, Shin TY, Kwon SJ, Jee SY, Seo BL, Shin SS, Yang DC, Kim 


\section{MEDIKORA Vol. IX, No 1 Oktober 2012}

HM, dalam Indian Journal of Medical Research, 2006 Aug; 124(2): 199-206, Seoul, Republic of Korea, dengan Judul; Pengaruh Panax ginseng pada waktu tikus diinduksiimobilitas dan fungsi kekebalan pada tikus.

21. Tentang ginseng menunjukkan sifat-sifat Anticarcinogenic diulas oleh Yun TK, Lee YS, Kwon HY, Choi KJ, dalam Journal Yao Li Xue Bao, 1996 Jul; 17 (4):293-8, Seoul, Republic of Korea, dengan Judul Kandungan Saponin dan efek anti kanker ginseng tergantung pada jenis dan usia tikus.

22. Mengurangi Cedera akibat Olah Raga diulas oleh Cabral de Oliveira AC, Perez AC, Merino G, Prieto JG, Alvarez AL, dalam Journal Comparative Biochemistry and Physiology C Toxicol Pharmacol. 2001 Nov; 130(3):369-77, Leon, Spain, dengan Judul; Efek pelindung Panax ginseng pada cedera otot dan inflamasi setelah latihan yang berlebihan.

23. Tentang melindungi Otot Dari Stres Olah Raga diulas oleh Voces J, Cabral de Oliveira AC, Prieto JG, Vila L, Perez AC, Duarte ID, Alvarez AI dalam journal Brazilian Journal of Medical and Biological Research, 2004 Dec; 37(12):1863-71. Epub 2004 Nov 17, Leon, Spain. Dengan judul; Pemberian Ginseng melindungi otot Rangka dari stres oksidatif yang diinduksi oleh latihan akut pada tikus.

24. Tentang meringankan Rematik Atritis diulas oleh Zhang JH, Wang JP, Wang HJ, dalam Journal Zhongguo Zhong Xi Yi Jie He Za Zhi, 2007 Jul; 27(7):589-92, Lanzhou, China. Dengan Judul Penelitian klinis pada efek total Panax Notoginseng saponin pada ketidakseimbangan lingkungan dalam tubuh dan kekebalan pada pasien rematik artritis.

25. Tentang peranannya dalam mengurangi Stres diulas oleh Lee SH, Jung BH, Kim SY, Lee EH, Chung BC, dalam Journal Pharmacological Research,2006 Jul; 54(1):46-9, Epub 2006 Mar 10, Cheongryyang, Seoul 130-650, Republic of Korea, dengan Judul; Efek Antistres saponin ginseng total dan ginsenoside Rg3 dan Rb1 dievaluasi oleh tingkat poliamina otak dibawah tekanan imobilisasi.

26. Tentang Panax Ginseng Terbaik untuk stres Kronis diulas oleh Rai D, Bhatia G, Sen T, Palit G, dalam The Journal of Pharmacological Sciences, 2003 Dec; 93(4):458-64, Lucknow, India, dengan judul Anti-stres efek Ginkgo biloba dan Panax ginseng: suatu Studi perbandingan.

27. Tentang herbal penghilang Stres diulas oleh Tachikawa E, Kudo K, dlam Journal of Pharmacological Sciences, 2004 Jun; 95(2) 140-4, School of Medicine, Iwate Medical 


\section{MEDIKORA Vol. IX, No 1 Oktober 2012}

Univercity, Japan, dengan judul Bukti kemanjuran misterius ginseng: Uji dasar dan percobaan klinis: penekanan fungsi modullary adrenal ginseng secara invitro.

28. Tentang Melawan rasa lelah diulas oleh Lin JH, Wu LS, Tsai KT, Leu SP. Jeang YF, Hsieh MT, dalam American Journal of Chinese Medicine, 1995; 23(2):167-72, Taipei, Taiwan, RO China. Dengan Judul Efek ginseng pada profil kimia darah dan tikus jantan yang diobati deksametason

29. Tentang Kesuburan Pria dan Panax Ginseng diulas oleh Park JS, Hwang SY, Lee WS, Yu KW, Paek KY, Hwang BY, Han K, dalam Journal Archives of Pharmacal Research, 2006 Sep;29(9) 800-7 The therapeutic effect of tissue cultured root of wild Panax ginseng C.A. Mayer on spermatogenetic disorder, dengan Judul; Efek Terapeutik akar jaringan Panax ginseng CA Mayer Liar yang dibudidayakan untuk gangguan spermatogenetic.

30. Tentang ginseng, perilaku Seksual dan Nitrit Oksida diulas oleh MurphyLL, Lee TJ, dalam Journal Annals of the New York Academy of Sciences, 2002 May; 962:372-7, Carbondale, Illinois 62901, USA, dengan Judul; Ginseng, Perilaku Seksual, dan Nitrit oksida.

31. Tentang Meningkatkan Sperma diulas oleh Zhang H, Zhou Q, Li X, Zhao W, Wang Y, Liu H, LiN, dalam Journal Mol Reprod Dev. 2007 Apr; 74(4): 497-501, Lanzhou, China, dengan Judul Ginsenoside Re meningkatkan kapasitas sperma manusia melalui jalur yang tergantung pada nitrit oksida.

32. Tentang meningkatkan kemampuan Otak Kaum anak-anak diulas oleh Reay JL, Kennedy DO, Scholey AB, dalam Journal of Psyhopharmacology, 2006 Nov; 20(6):771-81. Epub 2006 Jan 9, Northumbria University, Newcastle upon Tyne, NE1 8ST, UK dengan Judul; Pengaruh Panax ginseng, dikonsumsi dengan dan tanpa glukosa pada tingkat glukosa darah dan kinerja kognitif selama tugas berkelanjutan yang menuntut mental.

33. Tentang manfaat bagi anak-anak diulas oleh Reay JL, Kennedy DO, Scholy AB, dalam Journal of Psychopharmacology. (Oxfort, England) 2005 Jul; 19(4):357-65, Newcastle upon Tyne, UK. Dengan Judul Dosis Tunggal Panax ginseng (G115) mengurangi tingkat glukosa darah dan meningkatkan kinerja kognitif selama aktivitas mental yang berkelanjutan.

\section{F. Manfaat Ginseng}




\section{MEDIKORA Vol. IX, No 1 Oktober 2012}

Dari referensi buku-buku kuno di China dan kajian ilmu kedokteran modern manfaat Ginseng dapat disarikan sebagai berikut :

\section{GINSENG - Makanan Suplemen yang Menunjang Pengobatan}

Ginseng melalui penelitian farmakologi secara ilmiah, terbukti bahwa Ginseng bukan merupakan obat perangsang suatu ketika saja atau obat pembangkit energi. Serta bukan pula obat untuk pengobatan penyakit spesifik, akan tetapi merupakan sebuah zat yang dapat menjaga keseimbangan dan keadaan normal tubuh manusia. "Walaupun sifat dari Ginseng tergolong obat, namun tidak bersifat khas dan tidak beracun, tetapi tergolon jenis murni”.'oleh karena itu fungsi ginseng terhadap kesehatan organ-organ tubuh didasarkan pada fungsi peningkatan dan penyesuaian, ginseng tidak hanya dapat dianggap sebagai obat, tetapi juga merupakan makanan alami dan makanan kesehatan. Ginseng merupakan simbol makanan suplemen yang juga berfungsi pengobatan.

\section{Ginseng Berfungsi Menyeluruh}

Ginseng adalah tumbuh-tumbuhan alami, untuk dapat melihat penampilannya secara keseluruhan tidaklah mudah. Kasiat pengobatannya secara garis besar telah dibuktikan oleh hasil penelitian dan penemuan para ilmuwan masa kini, ilmu kedokteran modern juga telah mengenal ginseng yang sebenarnya dan telah menganugerahi status dan penghargaan sebagai rajanya obat-obtan tradisional cina.

Beberapa tahun ini berdasarkan pengaruh klinis ginseng dan farmakologisnya disimpulkan dalam "7 khasiat Ginseng" berikut :

a. Penyelamat energi; menghilangkan rasa lelah, meningkatkan stamina.

b. Menambah darah; memulihkan denyut jantung, mengobati anemia, tekanan darah rendah, jantung yang lemah.

c. Memelihara ketegangan jasmani dan rohani, bermanfaat bagi neurosis, urat syaraf otonomik yang tidak seimbang.

d. Menghilangkan rasa dahaga, mengobati kekeringan tubuh, bermanfaa bagi penderita kencing manis.

e. Menguatkan paru-paru, meringankan asma, bermanfaat bagi penderita asma kering yang disebabkan oleh penyakit tuberculosis (TBC).

f. Menyehatkan limpa menghentikan diare, bermanfaat bagi penderita usus, disentri, sembelit, tidak nafsu makan.

g. Mengeluarkan racun, menyembuhkan koreng, bermanfaat bagi bintil-bintil atau keloit beserta kulit yang kering. 


\section{MEDIKORA Vol. IX, No 1 Oktober 2012}

\section{Manfaat Bagi Lambung dan Usus (Gastrointestinal) :}

Gastrointestinal bagi yang tubuhnya sehat dapat dipastikan bahwa peristaltiknya teratur, peristaltik yang tidak teratur dapat menurunkan nafsu makan, dan dapat pula menyebabkan terjadinya sembelit atau desentri. Ginseng mempunyai manfaat untuk mengaktifkan fungsi gastrointestinal, sehingga dapat memperkuat daya serap pencernaan bahan makanan menambah stamina dan dapat menangkal serangan penyakit. Ginseng dapat pula mengobati gastrisis (peradangan kronis), gastroposis (turunnya posisi perut), nafsu makan berkurang Nyeri lambung, diare dan desentri, serta gastric ulcer (tukak lambung).

\section{Manfaat Untuk Melindungi Fungsi Hati}

Sebagaian besar penyakit hati terjadi karena bakteri pathogen, terutama infeksi yang disebabkan oleh bakteri pathogen tipe B, yang disebut Hepatitis B. Apabila tidak segera diobati kemungkinan akan terserang penyakit liver cirrhosis yang kemudian akan menjadi kanker hati. Ada lima pengaruh ginseng terhadap hati yaitu:
a. Meningkatkan peredaran darah, meningkatkan fungsi hati
b. Memperbanyak pembentukan nucleic acid (asam nukleat), protein dan lemak
c. Menyembuhkan kelelahan serta stress, meringankan beban hati (liver)
d. Memperbaiki kadar lemak tinggi di dalam darah, memperlancar pembuangan kolestrol keluar tubuh
e. Memperlancar proses metabolisme, membantu aktifitas hati

\section{Manfaat untuk Penyakit Jantung :}

Manfaat ginseng untuk pencegahan dan pengobatan penyakit jantung ;

a.

Menambah kelancaran

peredaran darah pada ujung pembuluh darah kapiler,

b.

Menambah elastisitas

pembuluh darah, menghindari penempelan kolestrol pada dinding pembuluh darah, mencegah pengerasan pembuluh darah.

c.

bermanfa $\mathrm{t}$ untuk

pembentukan darah, mencegah pen yakit anemia dan mengurangi beban jantung.

d.

Meningkatkan

metabolisme, menambah pemasok oksigen untuk sel-sel, agar otot-otot jantung bergerak secara aktif

e.

Meningkatkan daya

tangkal terhadap stress, membuat vitalitas menjadi lebih mantap 


\section{MEDIKORA Vol. IX, No 1 Oktober 2012}

f.

otonomik nervous sistem, dapat mencegah dan mengobati penyakit jantung.

g.

Bermanfaat

bagi

komplikasi jantung yang dikarenakan penyakit kencing manis (diabetes melitus) atau penyakit lambung dan usus (gastrointestine). Selain itu, perpaduan pengunaan ginseng dengan obat penyakit jantung, bebas efek samping dan melipat gandakan fungsinya.

\section{Manfaat Untuk Penyakit Diabetes Melitus (Kencing Manis) :}

Ginseng memiliki fungsi langsung terhadap pankreas, membuat pankreas dapat, memproduksi insulin dalam jumlah yang normal dan dapat mengontrol kadar gula di dalam darah, sehingga dapat secara berangsur-angsur kembali normal.

\section{Manfaat untuk Penyakit gynecologi (Organ reproduksi Wanita)}

Manfaat gingseng terhadap gangguan menopouse :

a.

Memiliki fungsi anti stress, mencegah atau meringankan ketidakseimbangansistem urat syaraf otonom.

b. Memiliki fungsi

memeperlancar sirkulasi darah, mencegah kemunduran ingatan.

c.

Memiliki fungsi

melancarkan hormon, memperlambat kemunduran hormon gonad.

\section{Manfaat Ginseng sebagai Pencegah Flu :}

Ginseng dapat mencegah flu, karena ginseng dapat memperbanyak sel darah merah, untuk dapat memperoleh oksigen yang lebih banyak dan mengaktifkan sel-sel untuk meningkatkan daya kekebalan. Dengan demikian daya tahan dalam tubuh juga meningkat, pada saat yang bersamaan ginseng juga dapat memperbanyak sel darah putih. Penggunaan ginseng setelah sembuh dari demam akibat flu dapat meningkatkan fungsi hati( lever) dan membasmi virus yang tersisa dalam hati, oleh karena itu ginseng juga bermanfaat untuk mencegah dan mengobati flu.

\section{Manfaat Ginseng Terhadap Penyakit Stroke :}

Ada 2 macam stroke, yaitu :

a.

Pendarahan (Cerebral

Hemorrage); pembuluh darah di dalam otak pecah, mengakibatkan pendarahan, darah mengalir keluar dan membeku pada otak. Sehingga sel-sel otak pada tempat yang membeku tidak dapat berfungsi, fungsi ginseng mencegah pengumpalan dan melarutkannya. 


\section{MEDIKORA Vol. IX, No 1 Oktober 2012}

b.

Pengumpalan darah

dalam pembuluh darah otak (cerebral Vascular Accident) ; stroke yang disebabkan oleh gumpalan darah (trombuse) dalam pembuluh darah otak, dikarenakan oleh terkelupasnya zat lemak yang menempel di dalam dinding pembuluh darah otak dan menyumbat pembuluh darah tersebut. Ginseng mempunyai fungsi melarutkannya, sehingga gumpalan atau trombusnya larut.

\section{Manfaat Ginseng untuk Ibu yang Sedang Hamil dan Anak-anak}

Diantara ibu dan Janin terdapat selaput amnion yang sangat tipis, fetus menerima zat gizi dari peredaran darah ibunya, dan darah antara ibu dan fetus tidak saling mencampur, sehingga makanan atau obat-obatan yang diserap oleh ibunya belum tentu dapat mempengaruhi fetus. Namun ada perkecualian bagi sebagaian obat tertentu, misalnya obat tidur dan obat penenang dapat memberikan dampak negatif bagi fetus. Ginseng adalah zat alamiah dan bukan obat, sehingga tidak ada efek sampingnya. Ginseng dapat memperbaiki peredaran darah dan menambah sel-sel darah untuk mengobati anemia. Oleh karena itu ginseng berguna bagi ibu yang sedang hamil dan tidak ada dampak negatifnya.

\section{Manfaat Ginseng Untuk Kecantikan}

Timbulnya jerawat, eksim, kulit kasar serta penyakit yang berhubungan dengan tidak sempurnanya sistem metabolisme tubuh. Kulit kita dapt menyerap kandungan ginseng yang efektif, sehingga dapat melancarkan, peredaran pembuluh darah subcutaneous. Oleh karena itu dengan minum ginseng kita dapat mengurangi gejala-gejala tersebut dan kulit kembali menjadi ceria dan bersinar. Jika ada luka atau jerawat maka bersamaan minum ginseng bubuk ginseng juga dioleskan sekitar yang luka atau jerawat, maka akan segera sembuh.

\section{KESIMPULAN}

Berdasarkan uraian tersebut di atas dapat disimpulkan bahwa:

1.

Ginseng memiliki

fungsi langsung terhadap pankreas, membuat pankreas dapat memproduksi insulin dalam jumlah yang normal dan dapat mengontrol kadar gula di dalam darah, sehingga pebderita diabetes mellitus dapat secara berangsur-angsur kembali normal.

2 .

Ginseng mempunyai

khasiat seperti: 1) Penyelamat energi ; menghilangkan rasa lelah, meningkatkan stamina, 2) Menambah darah ; memulihkan denyut jantung, mengobati anemia, tekanan darah rendah, jantung yang lemah, 3) Memelihara ketegangan jasmani dan rohani, bermanfaat 


\section{MEDIKORA Vol. IX, No 1 Oktober 2012}

bagi neurosis, urat syaraf otonomik yang tidak seimbang, 4) Menghilangkan rasa dahaga, mengobati kekeringan tubuh, bermanfaa bagi penderita kencing manis, 5) Menguatkan paru-paru, meringankan asma, bermanfaat bagi penderita asma kering yang disebabkan oleh penyakit tuberculosis (TBC), 6 Menyehatkan limpa menghentikan diare, bermanfaat bagi penderita usus, disentri, sembelit, tidak nafsu makan, 7) Mengeluarkan racun, menyembuhkan koreng, bermanfaat bagi bintil-bintil atau keloit beserta kulit yang kering.

\section{DAFTAR PUSTAKA}

Choi K, Kim M, Ryu J, Choi C, (2007). Ginsenosides compound K and Rh(2) inhibit tumor necrosis factor-alpha-induced activation of the NF-kappaB and JNK pathways in human astroglial cells, Journal Neuroscience Letters. 2007. Jun 21. Laboratory of Computational Cell Biology, Department of Brain and Bioengineering, Korea Advanced Institute of Science and Technology (KAIST), Daejeon 305-701, Republic of Korea

Jagetia G, (2007). Radioprotective Potential of Plants and Herbs against the Effects of Ionizing Radiation, Journal of Clinical Biochemistry and Nutrition, 2007. Mar; 40(2):74-81. Department of Radiobiology, Kasturba Medical College, Manipal, India

Cabral de Oliveira AC, Perez AC, Merino G, Prieto JG, Alvarez AI, (2001). Protective effects of Panax ginseng on muscle injury and inflammation after eccentric exercise. Journal Comparative Biochemistry and Physiology C Toxicol Pharmacol. 2001 Nov; 130(3):369-77,Department of Physiology, University of Leon, 24071, Leon, Spain

Cheng Y, Shen LH, Zhang JT (2005), Anti-amnesic and anti-aging effects of ginsenoside Rgl and Rbl and its mechanism of action, Acta Pharmacologia Sinica. 2005. Feb; 26(2):143-9, Institute of Materia Medica, Peking Union Medical College and Chinese Academy of Medical Sciences, Beijing 100050, China.

Geetha T, Saini A, Kaur IP. (2006). Ginseng extract exhibits antimutagenic activity against induced mutagenesis in various strains of Salmonella typhimurium, Journal Indian Journal of Experimental Biology, 2006 Oct; 44(10):838-41, Department of Pharmaceutics, University Institute of Pharmaceutical Sciences, Panjab University, Chandigarh 160 014, India.

Jiang QS, Huang XN, Dai ZK, Yang GZ, Zhou QX, Shi JS, Wu Q. (2007). Inhibitory effect of ginsenoside Rbl on cardiac hypertrophy induced by monocrotaline in rat, Journal of Ethnopharmacology . 2007 May 22; 111(3):567-72. Epub 2007 Jan 12, Chongqing Medical University, Department of Pharmacology, 400016 Chongqing, China

Karu N, Reifen R, Kerem Z. (2007). Weight gain reduction in mice fed Panax ginseng saponin, a pancreatic lipase inhibitor, Journal of Agricultural and Food Chemistry 2007 Apr 18; 55(8):2824-8. Epub 2007 Mar 17, Institute of Biochemistry, Food Science and Nutrition, and the Otto Warburg Minerva Center for Agricultural Biotechnology, The Faculty of Agricultural, Food and Environmental Quality Sciences, The Hebrew University of Jerusalem, Rehovot, Israel. 
Kim JH, Cho SY, Kang CW, Yoon IS, Lee JH, Jeong SM, Lee BH, Lee JH, Pyo MK, Choi SH, Quan SF, Lee JH, Choi CB, Rhim H, Nah SY. (2006). Ginseng saponins diminish adverse vascular effects associated with chronic methionine-induced hyperhomocysteinemia, Journal Biological and Pharmaceutical Bulletin. 2006 Dec; 29(12):2425-31, Department of Physiology, College of Veterinary Medicine, Chonbuk National University, Ginsentology Research Laboratory, Seoul, Republic of Korea.

Lee J, Jung E, Lee J, Huh S, Kim J, Park M, So J, Ham Y, Jung K, Hyun CG, Kim YS, Park D. (2007). Panax ginseng induces human Type I collagen synthesis through activation of Smad signaling, Journal of Ethnopharmacology. 2007 Jan 3; 109(1):29-34. Epub 2006 Jul 3, Biospectrum Life Science Institute, 101-701 SK VENTIUM, 522 Dangjung Dong, Gunpo City, 435-833 Gyunggi Do, Republic of Korea.

Lee SH, Jung BH, Kim SY, Lee EH, Chung BC. (2006). The antistress effect of ginseng total saponin and ginsenoside Rg3 and Rb1 evaluated by brain polyamine level under immobilization stress, Journal Pharmacological Research. 2006 Jul; 54(1):46-9. Epub 2006 Mar 10, Bioanalysis and Biotransformation Research Center, Korea Institute of Science and Technology, P.O. Box 131, Cheongryang, Seoul 130-650, Republic of Korea

Lee WK, Kao ST, Liu IM, Cheng JT. (2007). Ginsenoside Rh2 is one of the active principles of Panax ginseng root to improve insulin sensitivity in fructose-rich chow-fed rats, Journal Hormone and Metabolic Research. 2007 May; 39(5):347-54, Graduate School of Chinese Traditional Medicine, China Medical University, Taichung City, Taiwan, RO China

Lin JH, Wu LS, Tsai KT, Leu SP, Jeang YF, Hsieh MT. (1995). Effects of ginseng on the blood chemistry profile of dexamethasone-treated male rats, Journal American Journal of Chinese Medicine. 1995; 23(2):167-72, Department of Animal Science, National Taiwan University, Taipei, Taiwan, RO China

López MV, Cuadrado MP, Ruiz-Poveda OM, Del Fresno AM, Accame ME. (2007). Neuroprotective effect of individual ginsenosides on astrocytes primary culture, Journal Biochim Biophys Acta. 2007 Sep; 1770(9):1308-16. Epub 2007 Jun 28, Department of Pharmacology, School of Pharmacy, Complutense University, Madrid, Spain

Murphy LL, Lee TJ. (2002). Ginseng, sex behavior, and nitric oxide, Journal Annals of the New York Academy of Sciences. 2002 May; 962:372-7, Department of Physiology, Southern Illinois University, School of Medicine, Carbondale, Illinois 62901, USA

Park EK, Choo MK, Han MJ, Kim DH. (2004). Ginsenoside Rh1 possesses antiallergic and anti-inflammatory activities, Journal International Archives of Allergy and Immunology. 2004 Feb; 133(2):113-20. Epub 2004 Jan 21, College of Pharmacy, Kyung Hee University, Seoul, Republic of Korea

Park JS, Hwang SY, Lee WS, Yu KW, Paek KY, Hwang BY, Han K. (2006). The therapeutic effect of tissue cultured root of wild Panax ginseng C.A. Mayer on spermatogenetic 


\section{MEDIKORA Vol. IX, No 1 Oktober 2012}

disorder, Journal Archives of Pharmacal Research. 2006 Sep;29(9):800-7,College of Pharmacy, Chungbuk National University, Cheongju, Chungbuk 361-763, Republic of Korea.

Radad K, Gille G, Liu L, Rausch WD. (2006). Use of ginseng in medicine with emphasis on neurodegenerative disorders, Journal of Pharmacological Sciences. (2006) Mar; 100(3):175-86. Epub 2006 Mar 4, Department of Pathology and Clinical Pathology, Faculty of Veterinary Medicine, Assiut University, Egypt.

Rai D, Bhatia G, Sen T, Palit G, Journal The Journal of Pharmacological Sciences. (2003). Dec; 93(4):458-64, Anti-stress effects of Ginkgo biloba and Panax ginseng: a comparative study Division of Pharmacology, Central Drug Research Institute, Lucknow, India

Rausch WD, Liu S, Gille G, Radad K, Journal Acta Neurobiol Exp (Wars). (2006). 66(4):369-75 Neuroprotective effects of ginsenosides, Institute for Medical Chemistry, Veterinary Medical University, Veterindirplatz, 1 A-1210 Vienna, Austria

Reay JL, Kennedy DO, Scholey AB, Journal of Psychopharmacology. (Oxford, England) (2005). Jul; 19(4):357-65, Single doses of Panax ginseng (G115) reduce blood glucose levels and improve cognitive performance during sustained mental activity, Human Cognitive Neuroscience Unit, Northumbria University, Newcastle upon Tyne, UK

Reay JL, Kennedy DO, Scholey AB, Journal of Psychopharmacology. (2006). Nov; 20(6):771-81. Epub 2006 Jan 9, Effects of Panax ginseng, consumed with and without glucose, on blood glucose levels and cognitive performance during sustained 'mentally demanding' tasks, Human Cognitive Neuroscience Unit, Northumbria University, Newcastle upon Tyne, NE1 8ST, UK

Shen LH, Zhang JT, Journal of Neurological Research. (2004). Jun; 26(4):422-8. Ginsenoside Rg1 promotes proliferation of hippocampal progenitor cells, Institute of Materia Medica, Chinese Academy of Medical Sciences and Peking Union Medical College, Beijing, China

Shin HY, Jeong HJ; Hyo-Jin-An, Hong SH, Um JY, Shin TY, Kwon SJ, Jee SY, Seo BI, Shin SS, Yang DC, Kim HM, Journal Indian Journal of Medical research. (2006). Aug; 124(2):199-206, The effect of Panax ginseng on forced immobility time \& immune function in mice, College of Oriental Medicine, Institute of Oriental Medicine, Kyung Hee University, Hoegi-Dong, Dongdaemun-Gu, Seoul, Republic of Korea

Sun K, Wang CS, Guo J, Horie Y, Fang SP, Wang F, Liu YY, Liu LY, Yang JY, Fan JY, Han JY, Journal Life Sciences. 2007 Jul 19; 81(6):509-18. Epub (2007). Jun 28, Protective effects of ginsenoside Rb1, ginsenoside Rgl, and notoginsenoside R1 on lipopolysaccharide-induced microcirculatory disturbance in rat mesentery, Tasly Microcirculation Research Center, Peking University Health Science Center, Beijing, China 


\section{MEDIKORA Vol. IX, No 1 Oktober 2012}

Tachikawa E, Kudo K, Journal Journal of Pharmacological Sciences. (2004). Jun; 95(2):1404, Proof of the mysterious efficacy of ginseng: basic and clinical trials: suppression of adrenal medullary function in vitro by ginseng, Department of Pharmacology, School of Medicine, Iwate Medical University

Voces J, Cabral de Oliveira AC, Prieto JG, Vila L, Perez AC, Duarte ID, Alvarez AI, Journal Brazilian Journal of Medical and Biological Research. 2004 Dec; 37(12):1863-71. Epub (2004). Nov 17, Ginseng administration protects skeletal muscle from oxidative stress induced by acute exercise in rats, Departamento de Fisiologia, Universidad de Leon, Leon, Spain

Xia ZY, Liu XY, Zhan LY, He YH, Luo T, Xia Z, Journal of Thoracic and Cardiovascular Surgery. (2005). Aug; 130(2):258-64, Ginsenosides compound (shen-fu) attenuates gastrointestinal injury and inhibits inflammatory response after cardiopulmonary bypass in patients with congenital heart disease, Anesthesiology Research Laboratory, Renmin Hospital, Wuhan University, China

Xue JF, Liu ZJ, Hu JF, Chen H, Zhang JT, Chen NH, Journal Brain Research. 2006 Aug 23; 1106(1):91-8. Epub (2006). Jul 11, Ginsenoside Rb1 promotes neurotransmitter release by modulating phosphorylation of synapsins through a cAMP-dependent protein kinase pathway, Institute of Material Medica, Chinese Academy of Medical Sciences and Peking Union Medical College, Beijing 100050, China

Yue PY, Mak NK, Cheng YK, Leung KW, Ng TB, Fan DT, Yeung HW, Wong RN, Journal Chinese Medicine. (2007). May 15; 2:6, Pharmacogenomics and the Yin/Yang actions of ginseng: anti-tumor, angiomodulating and steroid-like activities of ginsenosides, Department of Biology, Faculty of Science, Hong Kong Baptist University, Kowloon Tong, Hong Kong SAR, China

Yun TK, Journal Lancet Oncology. (2001). Jan;2(1):49-55. Panax ginseng-a non-organspecific cancer preventive?, Laboratory of Experimental Pathology, Korea Cancer Center Hospital, Seoul, Republic of Korea

Yun TK, Lee YS, Kwon HY, Choi KJ, Journal Yao Li Xue Bao. (1996). Jul; 17(4):293-8, Saponin contents and anticarcinogenic effects of ginseng depending on types and ages in mice Laboratory of Experimental Pathology, Korea Cancer Center Hospital, Nowon-Ku, Seoul, Republic of Korea

Zhang H, Zhou Q, Li X, Zhao W, Wang Y, Liu H, Li N, Journal Mol Reprod Dev. (2007). Apr; 74(4):497-501, Ginsenoside Re promotes human sperm capacitation through nitric oxide-dependent pathway, Department of Medical Physics, Institute of Modern Physics, Chinese Academy of Sciences, Lanzhou, China

Zhang JH, Wang JP, Wang HJ, Journal Zhongguo Zhong Xi Yi Jie He Za Zhi. (2007). Jul; 27(7):589-92, Clinical study on effect of total panax notoginseng saponins on immune related inner environment imbalance in rheumatoid arthritis patients [Article in Chinese] Department of Rheumatology, Gansu Provincial People's Hospital, Lanzhou, China 
MEDIKORA Vol. IX, No 1 Oktober 2012 